Gaffar, A.K.

\title{
EFFECT OF LIME AND CELLULOSE TREATMENT ON DEACIDIFICATION OF ACID-SULPHATE SOILS DURING INUNDATION UNDER LABORATORY CONDITIONS
}

\author{
Abdul Karim Gaffar*)
}

\begin{abstract}
An experiment was conducted to assess the effects of lime and cellulose additions on deacidification of submerged acid sulphate soil in laboratory condition for 6 weeks duration. The results showed that untreated soil caused rapid decreasing in overlyingwater $\mathrm{pH}$, while soil $\mathrm{pH}$ increased slightly. Cellulose decomposed only in limed soil. Lime application at a rate equal to soil potential acidity was able to neutralize soil acidity and prevented overlying-water acidification.
\end{abstract}

KEYWORDS: Soil deacidification, acid sulphate soil, water acidification, lime, cellulose

\section{Introduction}

The formation of acidity from oxidized acid sulphate soil is attributed to the presence of acidic cations, i.e., aluminium and ferric ions and free sulfuric acid. Reclamation of acid sulphate soil involves drainage, leaching of acid and soluble salts, and application of lime and fertilizer (Dent 1986). Application of cellulosic organic matter has also been used to mitigate acid mine drainage (Bechard et al. 1994).

Deacidification of acid soil takes place during flooding, which involves reduction of $\mathrm{Fe}^{+++}$to $\mathrm{Fe}^{++}$, release of adsorbed $\mathrm{SO}_{4}{ }^{--}$or hydrolysis of basic sulphates, followed by oxidation of dissolved $\mathrm{FeSO}_{4}$ to ferric oxide and sulphuric acid at the soil-water interface, and removal of $\mathrm{H}_{2} \mathrm{SO}_{4}$ to surface water (Van Breemen 1976).

This laboratory scale experiment was designed to provide basic quantitative data on acidification-deacidification of submerged acid sulphate soil under controlled environment. It was anticipated that the results could be used for fishpond in the field.

") Researcher at Palembang Freshwater Research Station 


\section{Objective}

The objective of this experiment was to assess the effects of lime and cellulose addition on deacidification of submerged acid-sulphate soils, and any further effect on the chemical characteristics of the overlying-water.

\section{Materials and Methods}

Soil from the acidic horizon (60-100 $\mathrm{cm}$ depth) was taken by digging out a pit of $1 \times 1 \times 1.20 \mathrm{~m}$ in barren land. Bulk soil samples were separated into small clods and allow to air dry. The soil was mixed and ground to pass through a $2 \mathrm{~mm}$ mesh sieve.

The experiment was arranged in completely randomized design for 4 treatments with 3 replications, i.e.:

1. Control: no lime nor cellulose added to the soil

2. Organic enrichment: Cellulose added at $2.00 \mathrm{~g} / 100 \mathrm{~g}$ soil

3. Lime application: $\mathrm{CaCO}_{3}$ added at $1.20 \mathrm{~g} / 100 \mathrm{~g}$ soil

4. Liming and organic enrichment: $\mathrm{CaCO}_{3} 1.20 \mathrm{~g}+$ cellulose $2.00 \mathrm{~g}$ were added to every $100 \mathrm{~g}$ soil.

Each treatment consisted of $400 \mathrm{~g}$ soil to which the various additions had been made. Each was then placed in $30 \times 20 \times 14 \mathrm{~cm}$ polyethylene tank and inundated by 4 liters of distilled water. Additional water was applied weekly to compensate evaporation loss and sample removal for chemical analysis. Experimental tanks were placed in open air, but protected from direct sunlight and rain.

Overlying-water $\mathrm{pH}$ and sediment redox potential (Eh) were measured daily by $\mathrm{pH}$ meter (Digicon $\mathrm{pH}-210$ ) and redox probe Ingold connected to microprocessor (Labotec WTW PH 96). Total alkalinity and hardness were analyzed by titration methods, soluble iron by phenanthroleine method and soluble sulphate by turbidimetric method (APHA 1992). These parameters were measured weekly. Soil $\mathrm{pH}$, potential acidity, exchangeable acidity, exchangeable aluminium, available iron, and available sulphate were measured during initial period before treating with lime and cellulose, and in final period after overlying-water dried out.

Data were analyzed using one-way analysis of variance from Statgraphic statistical software package. 
Gaffar, A.K.

\section{Results}

\section{Submerged soil}

Under initial conditions the experimental soil had $\mathrm{pH}$ value of 3.5 , with potential acidity of $24.67 \mathrm{cmol}(+) / \mathrm{kg}$, and exchange acidity of $10.03 \mathrm{cmol}(+) /$ kg (Table 1).

Table 1. Chemical characteristics of soil at initial and final period of experiment related to different treatment.

\begin{tabular}{lrrrrr}
\hline \multirow{2}{*}{ Parameter } & Initial & \multicolumn{5}{c}{ Final } \\
\cline { 3 - 6 } & & Control & Cellulose & Lime & $\begin{array}{c}\text { Lime + } \\
\text { Cellulose }\end{array}$ \\
\hline $\mathrm{pH}$ & 3.5 & $3.9^{\mathrm{a}}$ & $3.9^{\mathrm{a}}$ & $7.4^{\mathrm{b}}$ & $7.10^{\mathrm{b}}$ \\
$\begin{array}{l}\text { Pot.acidity } \\
\text { (cmol(+)/kg) }\end{array}$ & 24.67 & $23.83^{\mathrm{a}}$ & $23.23^{\mathrm{a}}$ & $12.67^{\mathrm{b}}$ & $7.80^{\mathrm{b}}$ \\
$\begin{array}{l}\text { Exch.acidity } \\
\text { (cmol(+)/kg) }\end{array}$ & 10.03 & $9.07^{\mathrm{a}}$ & $9.30^{\mathrm{a}}$ & $0.17^{\mathrm{b}}$ & $0.10^{\mathrm{b}}$ \\
$\begin{array}{l}\text { Exch. aluminium } \\
(\mathrm{cmol} / \mathrm{kg})\end{array}$ & 7.88 & $7.57^{\mathrm{a}}$ & $7.10^{\mathrm{a}}$ & $0.00^{\mathrm{b}}$ & $0.00^{\mathrm{b}}$ \\
$\begin{array}{l}\text { Avail.iron } \\
(\mathrm{mg} / \mathrm{l})\end{array}$ & 27.50 & $25.98^{\mathrm{d}}$ & $9.51^{\mathrm{a}}$ & $4.24^{\mathrm{c}}$ & $12.12^{\mathrm{a}}$ \\
$\begin{array}{l}\text { Avail.SO } \\
(\mathrm{mg} / \mathrm{l})\end{array}$ & & & & & \\
\hline
\end{tabular}

Sharing same superscript letter in same row indicates no significant difference at $95 \%$ confidence limit.

After six weeks the submerged and redried soil acidity declined, and the levels of acidity were significantly different as a function of different treatments $(\mathrm{P}<0.05)$. Untreated soil in control tanks had a slight increase in $\mathrm{pH}$ value, while their potential and exchangeable acidity were slightly reduced.

Lime application to the soil prior to inundation resulted in significant rise in soil $\mathrm{pH}$, and reduction in soil potential acidity. Lime was able to neutralize all exchangeable aluminium, and reduce exchangeable acidity. 
Cellulose application to limed soil gave significant effect on reducing potential acidity. The final value of potential acidity was lower than that in tanks treated with lime alone.

Available iron in limed soil with cellulose was significantly higher than that in other treatments.

\section{Overlying-water}

Distilled water used to inundate soil had $\mathrm{pH}$ of 6.6 , total alkalinity of 4.60 mg $\mathrm{CaCO}_{3} / \mathrm{L}$ and total hardness of $3.8 \mathrm{mg} \mathrm{CaCO} / \mathrm{L}$, and no detectable iron or sulphate. After contact with the underlaid soil some chemical characteristics of the water changed, and the degree of chemical changes in the overlying water were significantly affected by different treatments.

Overlying water in control tanks immediately became acidic, the $\mathrm{pH}$ value declined from 6.6 to 4.0 within a day (Figure 1). On the other hand, the water with limed soil became alkaline and the $\mathrm{pH}$ value raised to 7.6 within a day and gradually increasing to 8.2 at the end of experiment. The chemical characteristics of overlying water at the end of experiment are presented in Table 2.

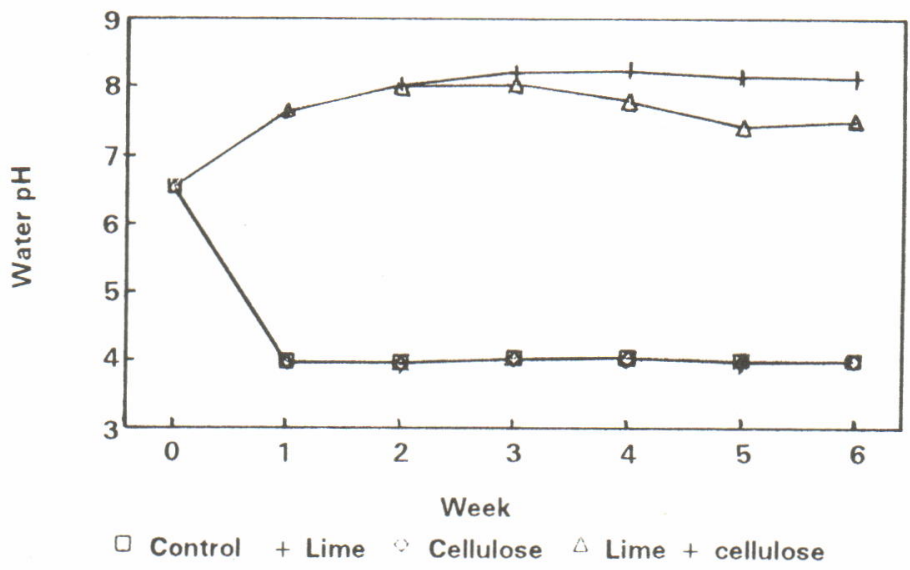

Figure 1. Mean water $\mathrm{pH}$ in tanks during 6 weeks of inundation.

Cellulose application failed to prevent acidification of overlying water. Statistical analysis indicated that water $\mathrm{pH}$ in tanks with soil treated by cellulose was not significantly different from that in control tanks $(\mathbf{P}>0.05)$. However, cellulose addition to limed soil resulted in lower water $\mathrm{pH}$ compared to that in tanks treated by lime alone. 
Gaffar, A.K.

Table 2. Selected chemical characteristics of overlying water at the end of experiment.

\begin{tabular}{lcrrrr}
\hline Treatment & pH & $\begin{array}{c}\text { Alkalinity } \\
(\mathbf{m g ~ C a C O} / 1)\end{array}$ & $\begin{array}{c}\text { Hardness } \\
(\mathbf{m g ~ C a C O} / 1)\end{array}$ & $\begin{array}{r}\text { Sol. iron } \\
(\mathbf{m g} / \mathbf{l})\end{array}$ & $\begin{array}{c}\text { Sol. } \mathrm{SO}_{4} \\
(\mathbf{m g} / \mathbf{l})\end{array}$ \\
\hline Control & $4.0^{\mathrm{a}}$ & $-0.70^{\mathrm{a}}$ & $79.40^{\mathrm{a}}$ & $0.83^{\mathrm{a}}$ & $717.99^{\mathrm{a}}$ \\
Cellulose & $4.0^{\mathrm{a}}$ & $-0.90^{\mathrm{a}}$ & $80.07^{\mathrm{a}}$ & $0.76^{\mathrm{a}}$ & $676.62^{\mathrm{a}}$ \\
Lime & $8.2^{\mathrm{c}}$ & $59.13^{\mathrm{b}}$ & $241.55^{\mathrm{b}}$ & $1.12^{\mathrm{a}}$ & $1091.44^{\mathrm{c}}$ \\
Lime + & $7.5^{\mathrm{b}}$ & $201.60^{\mathrm{c}}$ & $239.55^{\mathrm{b}}$ & $5.87^{\mathrm{b}}$ & $934.80^{\mathrm{b}}$ \\
cellulose & & & & & \\
\hline
\end{tabular}

Sharing same superscript letter in same column indicates no significant difference at $95 \%$ confidence limit.

There was significant difference in water alkalinity among treatments $(\mathrm{P}<0.05)$. Soil treated with lime plus cellulose gave the highest water alkalinity, while the lowest water alkalinity was found in control tanks. Total alkalinity in water overlying limed soil increased rapidly within the first week and then slowly decreased over the remaining five weeks of the experimental period (Figure 2). In tanks treated with lime and cellulose, total alkalinity of the overlying water increased over six weeks and the mean of total alkalinity concentration was significantly higher than that in limed soil without cellulose addition (Figure 3).

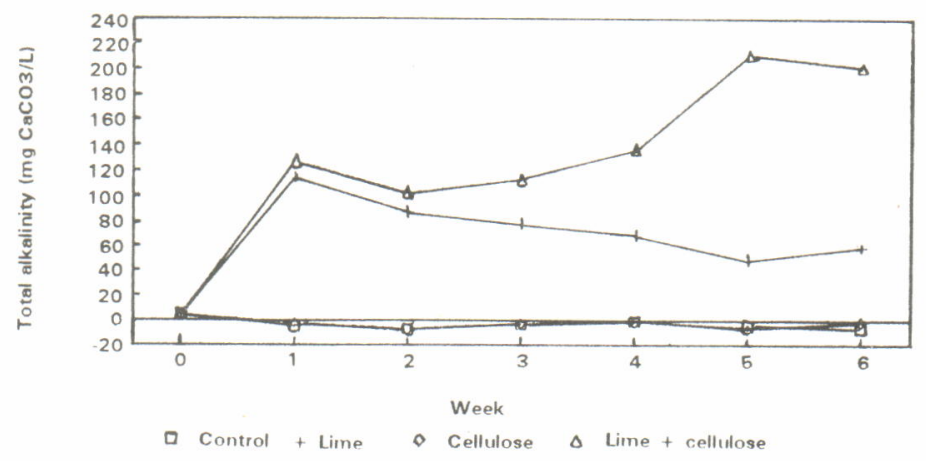

Figure 2. Redox potential in sediment-water interface in different treatment during 42 days of experiment.

Water hardness was significantly different among treatments $(\mathrm{P}<0.05)$ and increased in all treatments during six weeks of experimental period. Tanks treated with lime and lime plus cellulose showed higher increases throughout experiment (Figure 4). 


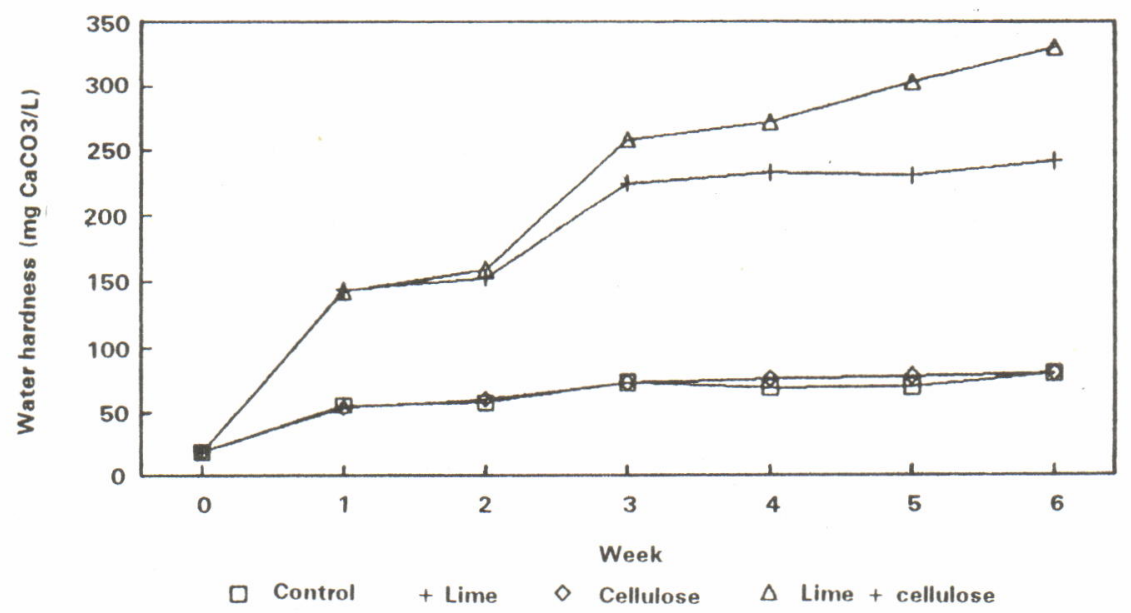

Figure 3. Mean of total alkalinity of overlying water during weeks of inundation.

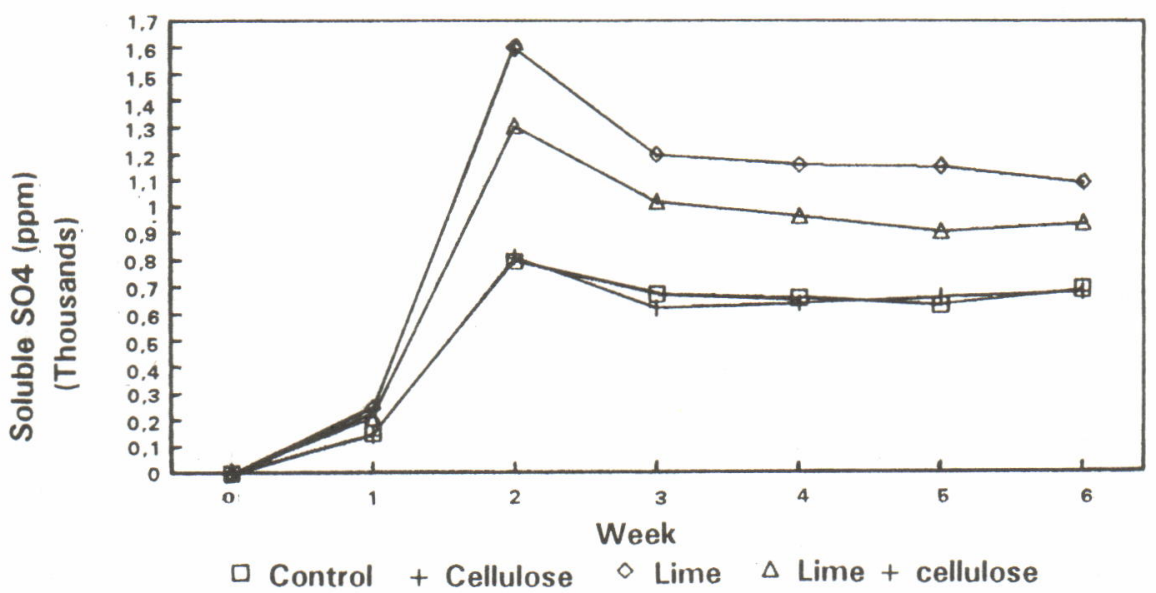

Figure 4. Mean of water hardness during 6 weeks of inundation.

Liming was also able to speed up sulphate release from the bottom soil. The highest sulphate concentration in overlying water was achieved in the second week and tended to decrease there after. Untreated soil gave a lower sulphate content in its overlying-water (Figure 5).

Although cellulose treatment of unlimed soil had no significant effect on releasing soluble iron to overlying-water, cellulose treatment of limed soil resulted in a significantly higher soluble iron concentration in its overlying- 
Gaffar, A.K.

water. Liming also did not give significant effect on soluble iron concentration in overlying water.

Cellulose treatment of unlimed soil had no significant effect on the sulphate concentration in overlying-water, but cellulose application to limed soil gave significant lower sulphate concentration than in limed soil without cellulose application (Figure 5).

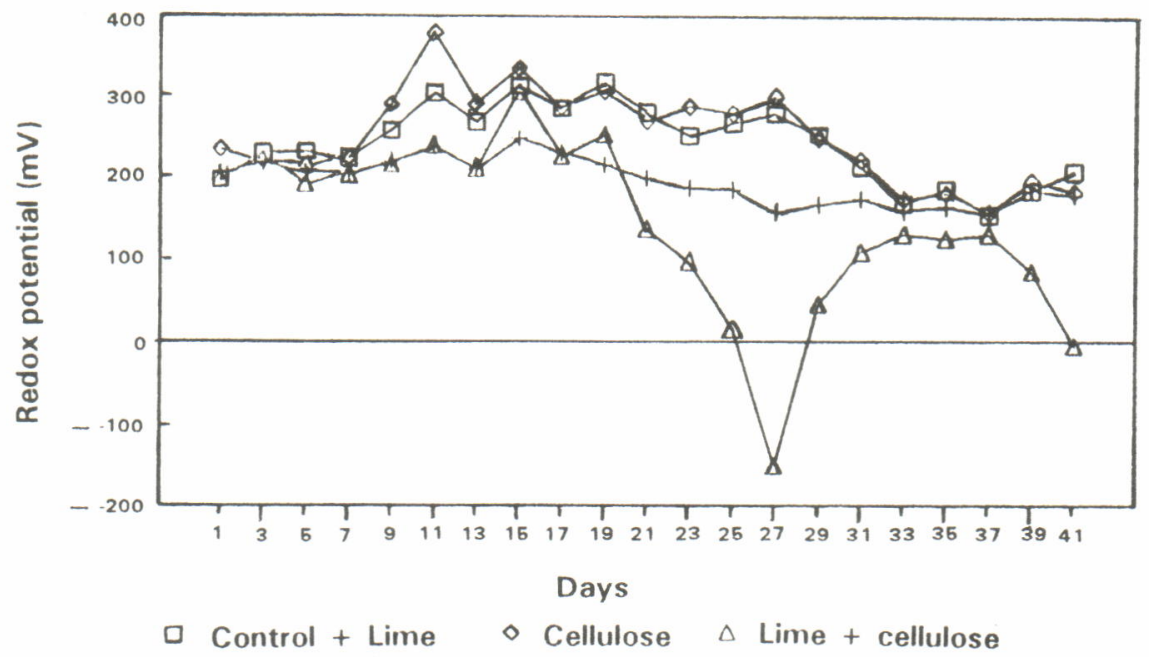

Figure 5. Mean of concentration of soluble sulphate in overlying water during 6 weeks of inundation.

Although cellulose treatment of unlimed soil had no significant effect on releasing soluble iron to overlying-water, cellulose treatment of limed soil resulted in a significantly higher soluble iron concentration in its overlyingwater. Liming also did not give significant effect on soluble iron concentration in overlying water.

Positive correlation existed between water $\mathrm{pH}$ and sulphate concentration in overlying water which can be expressed by the following regression equation:

$$
Y=348.81+85.8 X
$$

where $\mathrm{Y}=$ concentration of $\mathrm{SO}_{4}(\mathrm{mg} / \mathrm{L})$, and $\mathrm{X}=\mathrm{pH}$ value. Equation 1 has coefficient of correlation $r^{2}=0.91$, and is significant at a level of $99 \%$ confidence limit $(P<0.01)$. 


\section{Discussion}

The results showed that six weeks inundation of acid-sulfate soil caused dramatic acidification of their overlying waters, and released considerable amount of sulphate and iron. After being flushed and redried soil $\mathrm{pH}$ had increased by 0.4 unit. Lime application was obviously able to enhance deacidification of underlying soil and to prevent acidification of overlying water. Liming at a rate of $1.2 \mathrm{~g} \mathrm{CaCO} 3 / 100 \mathrm{~g}$ soil, the amount equal to soil potential acidity, was effective to alter the soil reaction from acid to alkaline. Soil $\mathrm{pH}$ increased from 3.5 to 7.4 , and soil exchange aluminium declined to the zero. Lime enhanced the release of soluble sulphate from suspended soil to overlying water. This finding is in agreement with that of Helyar and Anderson (1974). Shamsuddin and Auxtero (1991) explained that sulphate concentration in acid sulphate soil increased significantly with an increasing rate of dolomite application, because of increasing sulphate solubilization by lime. Moreover, Robarge and Johnson (1992) stated that as the $\mathrm{pH}$ of soil increased due to deacidification, reducing net positive charge of the $\mathrm{Al}^{+++}$and $\mathrm{Fe}^{+++}$oxides, as well as increasing of concentration of $\mathrm{SO}^{--}$in the soil solution took place due to the release of the adsorbed sulphate.

Overlying-water of limed soils had considerably higher total hardness concentration than its total alkalinity. Those conditions mean that calcium ion is not only reacted with bicarbonate but also with the other anions, especially sulphate (Boyd 1990). The increasing calcium and magnesium ion concentration as a result of lime application and increasing sulphate ions concentration in the solutions caused increasing water hardness far above alkalinity concentration.

The application of cellulose to unlimed soil had no significant effect on the release of sulphate and iron to the overlying water. This indicated that low $\mathrm{pH}$ condition was not conducive to cellulose decomposition. This finding failed to support the expected effect, as that this has been practiced in mitigation of acid mine drainage. The explanation for this finding is that unlimed soil having a low $\mathrm{pH}$ is unfavorable for organic matter (Attanandana and Vacharotayan 1986). Maneewon et al. (1987) also stated that in very acid soil the growth of microorganisms was not normal. Liming the soil would raise the $\mathrm{pH}$ and thus allow more normal growth of soil organisms.

Higher water alkalinity in soil treated with lime plus cellulose indicated that bicarbonate ion was available in higher concentration as the results of cellulose decomposition and dissolution of lime material itself.

Application of cellulose in combination with liming also enhance the releasing of soluble iron, due to additional energy source for bacterial activity in the presence of cellulose at higher $\mathrm{pH}$ levels, by reducing the ferric to more 
Gaffar, A.K.

soluble ferro form which was then released to overlying water. Gotoh and Patrick (1974) explained that the proportion of water soluble iron at all $\mathrm{pH}$ levels progressively increases with decrease in redox potential. Soluble iron begin to increase when the redox potential decreases to about $+150 \mathrm{mV}$ and continued to increase as the redox potential falls further. In this experiment redox potential had drastically decreased from $+257 \mathrm{mV}$ to $-215 \mathrm{mV}$ at the end of the third week of inundation (Figure 2), followed by soil color changes to black with some red-brown precipitate at the soil surface.

Extrapolation from the present results suggested that the amount of lime and cellulose needed for $1 \mathrm{~m}^{2}$ of pond bottom soil to $15 \mathrm{~cm}$ depth, with bulk density of $1.05 \mathrm{~g} / \mathrm{cm}^{3}$ is $1.89 \mathrm{~kg}$ of lime and $3.15 \mathrm{~kg}$ of organic matter.

In conclusion, the findings of this experiment are generally in agreement with earlier works, showing that the quality of overlying water is strongly affected by the nature of the bottom soil. Simply submerging and drying soil could reduce only a small amount of soil acidity. In very acid condition, organic matter, such as cellulose, added to the soil was not decomposed, and the treatment did not produce any significant effect on soil deacidification. Addition of $\mathrm{CaCO}_{3}$ in amount equal to soil potential acidity was effective in increasing soil $\mathrm{pH}$ to alkaline levels and in removing a considerable amount of both exchangeable and potential acidity, and supporting microbial activity to decompose the added organic matter.

\section{References}

APHA. 1992. Standard methods for examination of water and wastewater. $18^{\text {th }}$ Edition. American Public Health Association. Washington,DC.

Attanandana, T. and S.Vacharotayan. 1986. Acid sulphate soils: their characteristics, genesis, amelioration and utilization. Southeast Asian Studies. 24(2):154-180.

Bechard, G.; Yamazaki, H.; Gould, H.D. and P. Bedard. 1994. Use of cellulosic substrates for the microbial treatment of acid mine drainage. J.Environ.Qual. 23:111. 116.

Boyd, C.E. 1990. Water quality in ponds for aquaculture. Auburn University. Auburn. $482 \mathrm{pp}$.

Dent, D. 1986. Acid sulphate soils: a baseline for research and development. Publ.39. ILRI, Wageningen. 204 pp.

Gotoh, S. and W.H. Patrick. 1974. Transformation of iron in a water logged soil as influenced by redox potential and $\mathrm{pH}$. Soil Sci.Soc.Amer. Proc.38:66-70.

Helyar, K.R. and A.J.Anderson. 1974. Effects of calcium carbonate on the availability of nutrients in an acid soil. Soil Sci.Soc.Amer.Proc.38 : 341-346. 
Maneewon, M., Thawarnworg, N. and B. Tantisira. 1987. Study on rates of marl for rice production on acid sulphate soil in Thailand. In: H.Dost and N.van Breemen (Eds). Proc.Bangkok Symp.Acid Sulphate Soils.ILRI Publ 31. Wageningen.

Robarge, W.P and D.W. Johnson. 1992. The effect of acidic deposition on forested soil. Adv.Agr. $47: 1-83$.

Shamshuddin, J. and E. Auxtero. 1991. Soil solution compositions and mineralogy of some active acid sulphate soils in Malaysia as affected by laboratory incubation with lime. Soil.Sci. 152 (3):365-376.

Van Breemen, N. 1976. Genesis and solution chemistry of acid sulphate soils in Thailand. Center for Agricultural Publishing and Documentation, Wageningen. 263 pp. 